\section{Kumho Tire v. Carmichael}

Robert L. Heilbronner

Chicago Neuropsychology Group, Chicago, IL, USA

\section{Definition}

The issue in Kumho Tire v. Carmichael (1999) was whether the Daubert decision applies only to scientific ideas. On July 6, 1993, the right rear tire of a minivan driven by Patrick Carmichael blew out, which led to an accident resulting in the death of one passenger and severe injuries to others. The Carmichaels sued the tire maker claiming that the tire was defective. The Carmichaels had a tire expert testify that the tire was indeed defective and linked to the accident. However, the district court applied the Daubert standards and said that the methods used by the expert witness were not reliable and thus ruled in favor of Kumho. The Carmichaels appealed to the Eleventh Circuit court, claiming that Daubert was limited to scientific expert testimony and thus not applicable to "skill" or "experience-based observation." The Eleventh Circuit court reversed the decision in favor of the Carmichaels, holding that a Daubert analysis was restricted to purely scientific testimony mentioned in FRE 702. Kumho Tires subsequently asked the US Supreme Court to review whether Daubert was indeed limited to scientific evidence. The Court reasoned that the trial judge's gatekeeper function extended to all forms of expert witnesses including technical and experiential testimony and determined that the Daubert standard should be applied.

\section{Cross-References}

- Admissibility

- Daubert v. Merrell Dow

- Joiner v. General Electric (1997)

\section{References and Readings}

Daubert v. Merrell Dow, 509 US. 579 (1993).

Frye v. U.S., D.C. Cir, 293 F. 1013 (1923).

Greiffenstein, M. F. (2009). Basics of forensic neuropsychology. In J. Morgan \& J. Ricker (Eds.), Textbook of clinical neuropsychology. New York: Taylor \& Francis. Greiffenstein, M. F., \& Cohen, L. (2005). Neuropsychology and the law: Principles of productive attorneyneuropsychologist relations. In G. Larrabee (Ed.), Forensic neuropsychology: A scientific approach. New York: Oxford University Press.

Joiner v. General Electric, 522 U.S. 136 (1997).

Kumho Tire v. Carmichael, 526 U.S. 137 (1999). 